Article

\title{
School Market in Quebec and the Reproduction of Social Inequalities in Higher Education
}

\author{
Pierre Canisius Kamanzi \\ Faculty of Education, University of Montreal, Montreal, QC H2V 2S9, Canada; \\ E-Mail: pierre.canisius.kamanzi@umontreal.ca
}

Submitted: 11 June 2018 | Accepted: 31 August 2018 | Published: 10 January 2019

\begin{abstract}
The purpose of this article is to show that the stratification of the Quebec secondary school market contributes to the reproduction of social inequalities in higher education. The results obtained from a sample $(\mathrm{N}=2,677)$ of a cohort of students born in 1984 and observed up to the age of 22 show that the influence of social origin operates in large part via mediation of the type of institution attended. Students enrolled in private or public institutions offering enriched programs (in mathematics, science or languages) are significantly more likely to access college and university education than their peers who attended a public institution offering only regular programs. Additional analyses reveal that the probability of attending a private or public institution offering enriched programs is strongly correlated with the social origin of the student. The influence of the education market itself operates through differences in performance and educational aspirations that characterize students in the three types of establishments.
\end{abstract}

\section{Keywords}

education; education market; higher education; Quebec; school; social inequality; student

\section{Issue}

This article is part of the issue "Inequalities in Access to Higher Education: Methodological and Theoretical Issues", edited by Gaële Goastellec (University of Lausanne, Switzerland) and Jussi Välimaa (University of Jyväskylä, Finland).

(C) 2019 by the author; licensee Cogitatio (Lisbon, Portugal). This article is licensed under a Creative Commons Attribution 4.0 International License (CC BY).

\section{Introduction}

In Quebec, as in other developed societies, mass higher education has intensified since the 1980s. According to Savard and Bouthaïm (2006) and the Ministry of Higher Education, Research and Science (Ministère de l'Enseignement Supérieur, de la Recherche et de la Science, 2015), the rate of access to General and Vocational College (CEGEP), the first level of higher education and known in French as Collège d'enseignement général et professionnel (the equivalent of tertiarytype B education in OECD nomenclature), increased from $39.3 \%$ in $1975-1976$ to $53.3 \%$ in $1985-1986$, and to $60.8 \%$ in $1990-1991$, before stabilizing around $60 \%$ thereafter. The situation is more or less similar in university, where the rate of enrollment in a bachelor's degree program increased from $29 \%$ in 1984 to $36.7 \%$ in 2011 (Ministère de l'Éducation, 1999; Ministère de l'Éducation, du Loisir et du Sport, 2014). In other words, nearly two out of three students pursue higher education and one goes on to university. Despite this popularization, studies have shown that social inequalities in terms of access to this level of education persist (Chenard \& Doray, 2013; Dandurand, 1986, 1991; Sylvain, Laforce, \& Trottier, 1985). These inequalities have been attributed to differences in educational aspirations, which are themselves associated with the social and ethnic origin of students. According to Dandurand (1991), it is a "partial democratization", because gaps remain persistent between the French-speaking majority and the English-speaking or other-mother-tongue minorities, between men and women, as well as between young people of workingclass origin and their peers from wealthy families. Recently, Chenard and Doray (2013) have pointed out that even though the popularization of higher education in Quebec is steadily increasing, it remains an area of social 
reproduction, especially in university, where the effects of culture and family income are combined with the effects of academic pathways and experience.

In general, Quebec studies on inequalities in higher education have shown that these are the result of differences in academic pathways in high school taken by different social groups, which are attributable to power relations between social classes, genders and ethnicity (Dandurand, 1986, 1991). The resulting explanations are thus in line with the theory of social reproduction established by Bourdieu and Passeron (1970).

Although the explanatory scope of this theory is undeniable, we consider that it is limited. It would be as if the school system and the public policies that structure it were socially neutral. However, as Whelan, Nolan, Esping-Andersen, Maitre and Sander (2012) point out, the persistence of the reproduction of inequalities observed across several societies is strongly anchored in the evolution of public policies and the functioning of social institutions, educational systems in particular. As a result, the production of social inequalities stems from both the responsibilities assumed by the state and by families (Motel-Klingebiel, Tesch-Roemer, \& Von Kondratowitz, 2005).

The purpose of this article is to show that the persistence of unequal access to higher education in Quebec is dependent on public education policies via the structure of the education market. Paradoxically, the choice to introduce market practices in education was made in the name of fairness and educational democratization. Before illustrating this point with data, it would be useful to clarify the concept of education market and to give a brief overview of the writings on its links with academic (in)equality.

\section{Education Markets and the Democratization of Education: Convergence or Divergence?}

The recent evolution of education systems in several developed countries has been characterized by increased competition between schools, stimulated by the expansion of parents' freedom to choose schools for their children, as well as the possibility for schools to select or classify students. This dynamic of choice and competition has given rise to what has been termed an "education market" (Felouzis \& Perroton, 2007; Felouzis, Maroy, \& van Zanten, 2013; Teelken, 1999; van Zanten, 2006, 2009). Whether between parents or between schools, competition is based on the search for better quality of student training (Falabella, 2014). Parents find a good school for their children, while schools look for good students. However, several authors emphasize that the use of the market concept in the field of education must be more nuanced because of its rather "hybrid" character (Felouzis et al., 2013; Felouzis \& Perroton, 2007). Unlike other types of goods or service markets, the law of supply and demand is not defined by the partners but by government, which also regulates the quality of the goods and services traded (Ball, 1993). That is why several authors propose the term quasi-market (Bradley \& Taylor, 2002; Felouzis \& Perroton, 2007; Whitty, 1997).

The intensification of the education market through public policies in education has been the subject of conflicting debates between university researchers. Advocates, particularly in the United States, argue that freedom of choice and competition among schools improve efficiency while reducing inequities in access to quality education (Chubb \& Moe, 1988). Several studies come to this conclusion, as indicated in a meta-analysis performed by Belfield and Levin (2002) from 41 studies. On one hand, in most of the studies identified, there is a significant link between competition and student performance, graduation rate or dropout rate. On the other hand, there are many who, on the contrary, maintain that the education market is at the origin of some forms of social segregation. Belfield and Levin (2002) have submitted the hypothesis that the impact of competition in student performance is instead attributable to other factors created by competition, notably the quality and quantity of resources allocated to learning. As Felouzis et al. (2013) observe, it is difficult to measure the actual effect of competition between institutions, because the education market is moderated by contextual elements such as the characteristics of the local population (social and ethnic composition, quality and frequency of urban transit, type of urbanization, etc.). The work of Lubienski, Gulosino and Weitzel (2009) is consistent in this respect. These authors show that the efficiency of private schools is less related to market practices (competition) than to the socioeconomic characteristics of the students who attend them, especially since private schools are often located in neighbourhoods with a larger proportion of wealthy families.

Several studies carried out in other developed countries, notably in Great Britain (Bradley \& Taylor, 2002) and in Australia (Bradley, Draca, \& Green, 2004) concur. According to Bradley and Taylor (2002), the institutionalization of competition in 1992 between British high schools resulted in a general increase in student performance, regardless of the initial level of the institution. However, in terms of equity, the results veer in the opposite direction, revealing disparities between institutions. These disparities result from the polarization of students according to their social origin. Felouzis and Perroton $(2007,2009)$ note the consequences of ethnic and social segregation phenomena on the academic acquisition and orientation of students in French schools. According to these authors, competition results in the concentration of the weakest and most disadvantaged students in a small number of schools. Their marginalization leads to a drop in the quality of training by lowering expectations and requirements for success by the management of the institutions and by their teachers.

In short, the education market is a powerful instrument of social and academic segregation by which middle and upper-class families succeed in implementing strategies to avoid social and ethnic diversity (Bernal, 
2005; Felouzis \& Perroton, 2009). In the name of meritocracy, it allows these social classes to control access routes to university education, notably to prestigious institutions and sectors (Draelants, 2013).

However, the extent of the education market effect on segregation varies between societal contexts in accordance with the public policies and the social and cultural traditions that underpin these policies (van Zanten, 2006). Segregation would thus be less attributable to competition practices, per se, than to the polarization of students according to social origin that results from the practices of selection and the traditional organization of the school system, as evidenced by comparative studies in Europe by Dronkers and Avram (2009). Moreover, the importance of the education market and the extent of its effects on the production of inequalities vary over time within the same context. This is the case in Quebec. While the goal of equity and academic justice has been at the heart of education reforms since the 1960s, the Quebec school system has been progressively characterized by an inter- and intra-establishment hierarchization and stratification (Dandurand, 1991) that the sociologists (Lessard \& Levasseur, 2007; Marcotte-Fournier, Bourdon, Lessard, \& Dionne, 2016) attribute to the institutionalization of education market practices. This study thus argues that the intensification of the education market in recent decades contributes to maintaining or even increasing inequalities in higher education. Before illustrating this with empirical data, we briefly describe the characteristics of the Quebec education market in the following section.

\section{The Structure of the Quebec Education Market}

The Quebec school system is divided into four levels: preschool and elementary education, secondary education, CEGEP and university education. The compulsory education age is set at 16 years and the duration of secondary education is five years. The Quebec school system is made up of two types of institutions in both primary and secondary: private and public. Whether private or public, all schools in Quebec are under the control of the state in the sense that they must all respect and implement the same curriculum. According to the 2015 report of the Ministry of Education and Higher Education, there were 802 secondary schools of which 181 had a private status (almost a quarter). According to a recent report of the federation of private schools (Paradis, 2015), there were 87,500 students enrolled in private secondary schools, representing over $20 \%$ of secondary school students across the province. The same report indicates that more than one-third of Montreal's educational institutions (35\%) are part of the private network, compared to $12 \%$ in other urban regions with more than 500,000 inhabitants and 6\% elsewhere in Quebec. Private secondary schools are distinguished from public institutions by two major characteristics. First, they have the right to select their students on the basis of academic performance criteria and to expel those who subsequently fail to meet the standards of the school. Second, they have the right to charge parents tuition, a fee level that depends on whether or not they are subsidized (in part) by the government. As for public schools, they are under the obligation to unconditionally educate all students residing in their territory.

In addition to the division between private and public networks, the Quebec school market is characterized by the vertical differentiation of subjects, in both private and public institutions. Since the 1980s, the Public Education Act has allowed public secondary schools to develop special programs for so-called talented or gifted students. Gradually, several public institutions have adopted this strategy, especially in urban areas, in order to retain the "good" students who are migrating in increasing numbers to private institutions. Such a provision allows them to counter, or at the very least to confront, competition from the private sector, which continues to heighten. The expansion of special projects has given rise to curriculum differentiation which, in fact, now makes it possible to offer unequal training depending on the grade level of students (Marcotte-Fournier, 2015). There is a broad variety of enriched programs, but in general they focus on a small core of areas: mathematics, science, languages, arts and technology. In response to this differentiation, private institutions have adopted the same strategy to maintain competition with the public sector. In both cases, private and public, these enriched programs must be approved by the Ministry of Education. It is up to each school to decide on the number of places offered and admission criteria used to select or reject students.

The rapprochement of public and private institutions was further advanced by relaxing district school maps. While public schools are still obliged to provide schooling for all students residing within their territory, they are now allowed, though not compelled, to admit students residing outside their recruitment zones when parents request it. In other words, the law extends the freedom of parents to choose the school for their children outside their zone of residence, although this freedom remains subordinate to the right of the school to decide whether to admit this category of students and to set admission criteria.

In short, Québec's education system is characterized by a market model that was intensified in the 1980s. Combined within this market are the parents' freedom to choose a school for their children, competition between public or private institutions, and state control. While reforms since the 1960s have always placed school justice at the heart of the agenda, it is important to examine the extent to which the market model and the practices in place (curriculum differentiation, choice of school by parents, competition between schools) help to preserve school justice or, on the contrary, to challenge it. This study posits that the school market contributes to the reconstitution of inequalities in higher education. The following section describes the data and the strategies used for this purpose. 


\section{Data and Methodology}

\subsection{Data Source}

The analysis will be based on data from the Youth in Transition Survey (YITS) derived from a 10-year follow-up of a cohort of students from the age of 16 to 26. Conducted jointly by Statistics Canada and Human Resources and Skills Development Canada (HRSDC), this survey is an extension of the Program for International Student Assessment (PISA) conducted in 2000 by the OECD with 15-year-old students in 1999. In Canada, the PISA sample consisted of 29,687 students enrolled in 2000, of whom 4,450 were in the province of Quebec. Following this survey, Statistics Canada and HRSDC re-interviewed the subjects every two years over a 10-year period, from 2000 to 2010. The questionnaires used at Cycle 1 were used to gather information about the program year 2000 . Subsequently, surveys were repeated every two years. For example, the Cycle 2 questionnaire collected information on the educational and professional backgrounds of respondents over the period 2001-2002, Cycle 3 covered the period 2003-2004, and so on to Cycle 6, which collected information on the respondents' situation for the years 2009 and 2010.

In addition, the database used contains information on sociodemographic characteristics of various aspects of the life events (social or educational) collected by either PISA or YITS. However, we decided to use only the data collected up to Cycle 4 (2005-2006), when the respondents were 22 years old, for two reasons. Firstly, it represents the age when the majority of students have already started studying at one of the two levels of higher education: college or university. Secondly, it allows to consider students who exclusively undertook a "regular" schooling pathway and to avoid possible skewing from adults returning to studies, for which we do not have information that could control their effect (for example, the recognition of life experience in admission considerations).

\subsection{The Measure of Variables Studied}

The dependent variable in this article is access to higher education. It is measured by the highest level of schooling attended during the observation period (2000-2006), i.e., between 16 and 22 years of age. Three categories were considered: (1) high school education, which, for us, corresponds to a failure to pursue higher education, (2) college studies and (3) university studies. It is therefore an ordinal variable because, in Quebec, college and university constitute two successive and non-parallel levels, as it is the case in many educational systems, particularly in the United States and the rest of Canada. In other words, access to university is conditional upon graduation from college and the transition to college requires a high school diploma.

Two independent variables are at the heart of this study: the social origin of the student and the stratifi- cation of the education market. Social origin has been measured by two dimensions, respectively, of academic capital and family economics: (1) the education level of the most educated parent and (2) the annual income of both parents. The stratification of the education market was measured by the type of secondary school attended or the curriculum followed by the secondary school student. Respondents were grouped into three categories: (1) those who attended a private school, (2) those who attended a public school, but took enriched courses in language, science or mathematics, and (3) those who attended a public school but attended only the regular public school track. Table 1 summarizes the overall portrait of the sample according to the three variables.

Table 1. Distribution of respondents by social origin and type of secondary school attended.

\begin{tabular}{lcc}
\hline Education level of parents & $\mathbf{N}$ & \% \\
\hline High school or less & 937 & 35 \\
College & 1,070 & 40 \\
University & 669 & 25 \\
Annual income of both parents & & \\
1st quartile & 669 & 25 \\
2nd quartile & 615 & 23 \\
3rd quartile & 589 & 22 \\
4th quartile & 803 & 30 \\
Type of school or class attended & & \\
$\quad$ Regular public & 1,365 & 51 \\
Enriched public & 883 & 33 \\
Private & 428 & 16 \\
All & 2,677 & 100 \\
\hline
\end{tabular}

Regarding control variables, the analysis takes into account three groups of variables recognized for their influence on access to higher education that are both related to socioeconomic background and the education market: (1) academic performance, (2) educational aspirations and (3) sociodemographic characteristics. The student's academic performance was measured by PISA reading scores. As for educational aspirations, they were measured by the highest level of study foreseen by students at the age of 15 years. Finally, the analysis also takes into account the student's gender and place of residence (urban/rural) of their parents.

\subsection{Statistical Analysis Model}

Since the dependent variable studied is ordinal, ordinal logistic regression analysis with the logit function (Allison, 2003) was applied. Specifically, the cumulative logit model was used. This consists of comparing the upper cumulative categories of the studied variable with the lower cumulative categories. Since the dependent variable studied in this case has three categories, the model estimates the cumulative probability of a respon- 
dent belonging to either category 2 (college) versus 1 (high school), or category 3 (university) versus 1 and 2 .

\section{Results}

After graduation from high school, the majority of young Quebecers pursue higher education in college. The results in Table 2 show that by the age of $22,70 \%$ of respondents had attended college at some point. Half of them (35\%) had accessed university. However, the rate of access to one or the other level varies significantly according to the social origin of the student (parental education level and income), but also according to the type of institution attended in high school. Thus, the college transition rate is 54\% among those whose parents hold at most a high school diploma, while it is $89 \%$ when at least one parent has a university degree. These inequalities are maintained or even increase at the university level. While the probability of going to university is $20 \%$ when neither parent has gone beyond high school, it increases to $32 \%$ when at least one parent has a college diploma and $60 \%$ if a parent has a university degree, triple the rate for the first category. These disparities are more or less similar for parental income levels, albeit less significant.

Access to higher education is also associated with the type of institution attended in high school. Students enrolled only in regular programs in public schools access college at a rate of $49 \%$, versus almost all students in private schools (94\%) or public institutions with enriched programs in mathematics, science and languages (91\%). The gaps widen even more at university, where the transition rates are, respectively, $15 \%, 51 \%$ and $60 \%$. The education market therefore has an effect on the production of significant inequalities in access to higher education, particularly to university. Significant differences exist not only between students in the private versus public sector, but also and especially among those who have enrolled in regular programs versus enriched programs in the public sector.
The following ordinal logistic analyses (see Table 3) seek to estimate the relative influence of each of these two variables. As a first step, bivariate analyses were performed to determine the gross effect of each of the different variables (independent and control) that will be included in the model. The results show that this effect is significant for all variables. In a second step, multiple regression analyses were carried out. Model 1 includes both the social origin and the type of institution attended. The results reveal that, when taking into account the school attended, the influence of the student's social origin remains significant, but decreases considerably. This supports the hypothesis that the effect of social origin is mediated by the type of school attended. In other words, social background influences the choice of type of high school attended, which, in turn, influences the chances of accessing higher education. Conversely, when the social background is taken into account, the influence of the school attended decreases considerably: when the socioeconomic status of the parents is comparable, the inequalities between students attending the private and the enriched public schools disappear but remain significantly high compared to their peers in the regular stream. This supports the hypothesis of an interaction between the two variables. In other words, the influence of social origin (parental socioeconomic status) varies according to the type of institution attended and vice versa. The fact that private school students globally access higher education (both college and university, $\beta=.347, \mathrm{p}<.001$ ) in a relatively higher proportion than their peers in the enriched public stream (see Bivariate analysis) is thus partly due to differences in social origin. The first group comes, more often, from wealthy families. For example, a further analysis shows that $50 \%$ of those who attended a private high school have at least one parent with a university degree while it is $29 \%$ and $14 \%$ for those who respectively attended enriched and regular curriculum in public school.

Table 2. Access to higher education according to the social origin of the student and the type of high school attended (\%).

\begin{tabular}{|c|c|c|c|}
\hline & No access to CEGEP & High school $\Rightarrow$ CEGEP & CEGEP $\Rightarrow$ University \\
\hline \multicolumn{4}{|c|}{ Education level of parents } \\
\hline High school & 46 & 54 & 20 \\
\hline College & 37 & 63 & 32 \\
\hline University & 11 & 89 & 60 \\
\hline \multicolumn{4}{|c|}{ Annual income of both parents } \\
\hline 1st quartile & 41 & 59 & 23 \\
\hline 2nd quartile & 35 & 65 & 27 \\
\hline 3rd quartile & 24 & 76 & 37 \\
\hline 4th quartile & 22 & 78 & 46 \\
\hline \multicolumn{4}{|c|}{ Type of school or class attended } \\
\hline Regular public & 51 & 49 & 15 \\
\hline Enriched public & 9 & 91 & 51 \\
\hline Private & 6 & 94 & 60 \\
\hline All & 30 & 70 & 34 \\
\hline
\end{tabular}


Table 3. Ordinal logistic regression coefficients.

\begin{tabular}{|c|c|c|c|}
\hline & Bivariate & Model 1 & Model 2 \\
\hline & $\beta$ & $\beta$ & $\beta$ \\
\hline \multicolumn{4}{|l|}{ Independent variables } \\
\hline \multicolumn{4}{|l|}{ Education level of parents } \\
\hline High school & $-.792 * *$ & $-.526 * * *$ & $-.265^{* *}$ \\
\hline College & Reference & Reference & Reference \\
\hline University & $1.100 * * *$ & $.692 * * *$ & $.491 * * *$ \\
\hline \multicolumn{4}{|l|}{ Annual income } \\
\hline 1st quartile & $-.252 * * *$ & -.135 (NS) & -.118 (NS) \\
\hline 2nd quartile & Reference & Reference & Reference \\
\hline 3rd quartile & $.476 * * *$ & $.251^{*}$ & .120 (NS) \\
\hline 4th quartile & $.727^{* * *}$ & $.497^{* *}$ & $.293^{*}$ \\
\hline \multicolumn{4}{|c|}{ Type of school or class attended } \\
\hline Regular public & $-2.027 * * *$ & $-1.817^{* * *}$ & $-1.019 * *$ \\
\hline Enriched public & Reference & Reference & Reference \\
\hline Private & $.347^{* * *}$ & .214 (NS) & $.466 * *$ \\
\hline \multicolumn{4}{|l|}{ Control variables } \\
\hline PISA reading scores & $1.667^{* * *}$ & - & $.711 * * *$ \\
\hline \multicolumn{4}{|l|}{ Educational aspiration level } \\
\hline High school & Reference & - & Reference \\
\hline College & $1.933 * * *$ & - & $1.452 * * *$ \\
\hline University & $3.436 * * *$ & - & $2.380 * * *$ \\
\hline Didn't know & $1.499 * * *$ & - & $1.488 * * *$ \\
\hline Gender (female) & $.635^{* * *}$ & $.930 * * *$ & $.611 * * *$ \\
\hline Residential location (urban) & $.604 * * *$ & $.262^{*}$ & .058 (NS) \\
\hline Pseudo $\mathrm{R}^{2}$ & & .1864 & .2886 \\
\hline Wald $\chi^{2}$ & & 726.00 & 895.16 \\
\hline Degree of freedom & & 9 & 13 \\
\hline $\mathrm{N}$ & & 2,677 & 2,677 \\
\hline
\end{tabular}

Notes: ${ }^{*} \mathrm{p}<0.05 ;{ }^{* *} \mathrm{p}<0.01 ;{ }^{* * *} \mathrm{p}<0.001 ; \mathrm{NS}$ : not significant at 0.05 .

Model 2 verifies the hypothesis that the effect of the type of secondary school attended on access to higher education is exerted through differences in academic performance (measured here by PISA scores in reading) and students' educational aspirations. While Model 1 does not show a significant difference between private and enriched schools, the difference reappears when performance and academic aspirations are included in the analysis. In other words, with similar aspirations and academic performance, private school students are more likely to access higher education than their peers in the enriched programs in public schools. This suggests the hypothesis that the high rate of access to higher education among students from enriched programs in public institutions is attributable to their high level of educational aspirations, but especially to their academic performance.

In sum, the influence of social origin on access to college or university is partly mediated by the type of high school or program followed (enriched or regular). On the other hand, the influence of the type of institution is in turn mediated by the differences in performance and educational aspirations that characterize the students in private, enriched public and regular public programs.

\section{Discussion}

The results of this study confirm our hypothesis that the structure of the Quebec secondary school market, through its inter- and intra-institutional stratification character, exerts an important influence on the social reproduction of inequalities in higher education. Existing literature (Felouzis, 2009; Jenkins, Micklewright, \& Schnepf, 2008) posits three possible interpretations, although their relative weight depends greatly on the societal context. The first refers to differences in the quality of education based on the different types of school or course of study to which students have access within these institutions. As a review of the writings of Rompré (2015) and the analysis of Quebec's Conseil Superieur de l'Éducation (2016) show, the segregations that characterize this differentiation have the effect of offering unequal education, both on a cognitive and non-cognitive level. 
At the same time, teachers and principals tend to raise the level of expectations and demands on students because they are confident that they will be able to respond to them.

The stratification of the education market would also have the effect of creating an uneven distribution of financial and educational resources between schools and classes. In the case of selective training and schools, administrators tend to mobilize more pedagogical resources (technologies, libraries, etc.) for organizing school and extracurricular activities (competitions for prizes, trips, etc.) to further raise the level of students who are already strong in terms of knowledge and culture. Although poorly documented and not officially recognized, such inequalities between institutions certainly exist in Quebec (Karsenti \& Collin, 2013).

Differences in access to higher education can also be attributed to differences in the institutional environment. The higher the expectations of students, the more strategies are mobilized to make the school environment conducive to learning and effective organization (Bryk \& Lee, 1992; Dronkers \& Robert, 2008). In Quebec, private schools have always been deemed to have a better quality of supervision that promotes student success (Brassard, 2006).

The second track relates to differences in scholastic experience. The stratification of schools and classes is not without effect on students' school experiences (Felouzis, 2009). If students who attend selective institutions and classes-private schools and enriched programs in the public sector in Quebec-demonstrate high academic performance and aspirations, it should be because they have developed a sense of confidence in themselves (Sheldrake, 2016). Thus, being enrolled in a private institution or an enriched class would be interpreted as a form of merit, recognition of the skills to succeed and perform that would, in turn, generate a sense of confidence and commitment to education. As Teese (1998) pointed out, the selection of students and the stratification of classes or institutions create and maintain a culture of elitism and social hierarchy among students themselves.

The third track deals with the social and academic composition of the group of students attending a school (Dronkers \& Robert, 2008). The stratification of institutions and classes tends to favour the polarization of classes based on the level of school performance and social origin. From this point of view, this polarization tends to homogenize students' school experiences through the mutual influence of their peers in terms of their educational aspirations, their commitment to studies and the valuation of success. It could be argued that students in the private and the enriched public sectors maintain a high level of academic performance and aspirations due to peer interactions, a culture of competition and collaboration within the institution. In sum, additionally to the favourable effects of schooling and social origin, the students' aspirations to pursue higher education are contin- ually modeled by the "school effect" (Draelants, 2013), through the quality of cognitive and non-cognitive training, the resources allocated, peer influence, and the quality of the institutional environment.

\section{Conclusion}

The purpose of this article was to examine the extent to which the stratification of the Quebec secondary school market contributes to the reproduction of inequalities in access to higher education. The results of our analyses reveal three main findings. First, although higher education is accessible to the majority of young people, there are still significant disparities based on social origin. The analysis reveals, however, that the influence of the latter operates largely through the mediation of the type of school attended and the courses or pathways offered within them. Students who attended a private or public institution with enriched programs (in mathematics, science or languages) are significantly more likely to have access to college and university education than their peers who followed the regular stream in a public institution. However, additional analyses reveal that the probability of attending a private or public institution with enriched programs is strongly correlated with the social origin of the student. Secondly, the influence of interand intra-institutional stratification is itself mediated by the performance inequalities of students. In this study, we examined the effect of school performance as measured by PISA scores and by student achievement at the end of high school.

In the end, the results of this study confirm the hypothesis that unequal access to higher education in Quebec is reflected in the stratification of the education market. In a context of equal opportunities, supported by the free and compulsory nature of primary and secondary education, the education market serves as an instrument of segregation that allows middle and upperclass families to preserve their privileges. In the name of social justice and systemic efficiency, the right to choose one's school favours and perpetuates the homogenization of students according to their social origin and academic performance. Since this homogenization is accompanied by an unequal supply of education and by school segregation, students are subject to an uneven educational and professional future, as the results of this study testify. However, this study has examined only two factors related to the education market, which is complex and contains other aspects that need to be examined. To bridge this gap, further studies may focus on academic performance in subjects other than reading. On the noncognitive level, it would be interesting to study the effect of interactions among students, between students and school staff (e.g., teachers or guidance counsellors), differences in various resources and the internal climate. In addition, our study was limited to examining inequalities of access. Future research could expand to other areas, such as field of study, academic perseverance and grad- 
uation. From a methodological point of view, it would have been useful to use the model of structural equations, allowing direct and indirect effects to be distinguished, but the distribution of certain variables did not allow us to carry out such an analysis, which forced us to limit ourselves to logistic analyses.

Despite these limitations, this study has produced interesting results both theoretical and political. On the theoretical side, its main contribution is to illustrate that the question of reproducing social inequalities has become more complex since the governments of many countries instituted and strengthened their policies of equal opportunity. Several previous studies associate these inequalities with sociodemographic characteristics, in particular socioeconomic origin and the way education systems are structured (Dubet, Duru-Bellat, \& Vérétout, 2010; Pechar \& Andres, 2011). Most of these studies focus on either of these two factors. The distinguishing characteristic of this article is to have attempted, from the data available, to take both into account.

International comparison studies distinguish two types of education systems: differentiated and comprehensive (Dubet et al., 2010; Dupriez \& Dumay, 2006; Felouzis, 2009; Marks, 2005). The former are characterized by early student separation and orientation into hierarchical streams that usually operate on the basis of academic performance. Conversely, comprehensive systems are distinguished by a long-term common training structure. Selection and orientation in hierarchical streams occur much later, if at all, and the number of selective courses is limited. The ultimate goal of this long-term joint training is to provide all students with an equivalent educational background so as to minimize the effects of family resources on student performance, as well as access to higher education and vocational guidance. The educational and vocational guidance that follows this common core therefore relies more on student choice and accumulated skills than on the cultural and economic capital of the parents.

As noted in the studies cited above, Canadian provinces, including Quebec, are part of comprehensive school systems. In Quebec, orientation into general or professional education streams starting from the third year of secondary school is based on student choice and not on any sort of selection. In addition, the system allows students to change their orientation. In this respect, the structure of the education system is egalitarian. On the one hand, the egalitarian vision officially promoted in public policies has been compromised by social segregation spurred by the expansion of the school market in recent decades (Lessard \& Levasseur, 2007). As discussed earlier, this segregation takes place through competition between the network of private and public institutions, which has led to intra-institutional competition, differentiated education and horizontal stratification in secondary education (Kamanzi \& Maroy, 2017; Maroy \& Kamanzi, 2017). The practices at the heart of this segregation are neither generalized nor obligatory. It is be- cause of the intervention of social actors (in particular, parents' associations) that the segregation has been established. On the other hand, these practices have been accepted and even supported by the state, notably via the financing of private schools and enriched programs in public schools. Finally, this article shows, using the example of Quebec, that the production of inequalities in higher education is modulated by the interaction between public policies and the social background of students. In other words, the influence of social origin varies as a function of public policies and vice versa. While recognizing that the relative weight of each varies according to societal context and the socioeconomic climate, it can be argued that such a conclusion applies to all school systems (Dubet et al., 2010; Draelants, 2013).

On the political level, this study justifies the relevance of a reflection on educational policies in Quebec. While the institutionalization of curriculum differentiation is justified by the need to take into account the aptitudes and the individual needs of students, it should still be necessary to preserve the principles of justice and social equity. Although this differentiation is inevitable in the current context, a reflection on educational policies is required to increase the social and academic diversity of students and to avoid or, at the very least, to curb the hierarchy of classes and institutions based on social origin, which the various school reforms since the 1960s have always sought to end (Conseil Superieur de l'Éducation, 2016).

\section{Acknowledgments}

I would like to thank Claude Trottier for his very pertinent comments on this article, Peter Wheeland and Tya Collins for their careful reading of this text.

\section{Conflict of Interests}

The author declares no conflict of interests.

\section{References}

Allison, P. D. (2003). Logistic regression. Using the SAS system: Theory and application. Cary: SAS Institute Inc.

Ball, S. (1993). Education markets, choice and social class: The market as a class strategy in the UK and the USA. British Journal of Sociology of Education, 14(1), 3-19.

Belfield, C. R., \& Levin, H. M. (2002). The effects of competition between schools on education outcomes: A review for the United States. Review of Educational Research, 72(2), 279-341.

Bernal, J. L. (2005). Parental choice, social class and market forces: The consequences of privatization of public services in education. Journal of Education Policy, 20(6), 779-792.

Bourdieu, P., \& Passeron, J.-C. (1970). La reproduction. Éléments pour une théorie du système d'enseignement 
[Reproduction. Elements for a theory of the educational system]. Paris: Éditions de Minuit.

Bradley, S., Draca, M., \& Green, C. P. (2004). School performance in Australia: Is there a role for quasimarkets? Australian Economic Review, 37(3), 271-286.

Bradley, S., \& Taylor, J. (2002). The effect of the quasimarket on the efficiency-equity trade-off in the secondary school sector. Bulletin of Economic Research, 54(2), 295-314.

Brassard, A. (2006). L'évolution de la gestion scolaire depuis les années 1950 [The evolution of school management since the 1950s]. Le Point en administration scolaire, 8(4), 22-27.

Bryk, A. S., \& Lee, V. E. (1992). Is politics the problem and market the answer? An essay review of politics, markets, and America's schools. Economics of Education Review, 11(4), 439-451.

Chenard, P., \& Doray, P. (2013). L'accessibilité aux études postsecondaires au Québec. Quelles démocratisations? [Accessibility to postsecondary studies in Quebec. What democratization?] In P. Chenard, P. Doray, L.-É. Dussault, \& M. Ringuette (Eds.), L'accessibilité aux études postsecondaires. Un projet inachevé (pp. 49-67). Montréal: Presses de l'Université du Québec.

Chubb, J. E., \& Moe, T. E. (1988). Politics, markets, and the organization of schools. The American Political Science Review, 82(4), 1065-1087.

Conseil Superieur de l'Éducation. (2016). Remettre le cap sur l'équité. Rapport sur l'état et des besoins de l'éducation 2014-2016 [Refocusing on the equity cap. Report on the state and needs of education 2014-2016]. Québec: Gouvernement du Québec.

Dandurand, P. (1986). Rapports ethniques et champ universitaire [Ethnic relations and university]. Recherches sociographiques, XXVII(1), 41-77.

Dandurand, P. (1991). Mouvements de la scolarisation, conditions de vie et politiques d'accessibilité à l'université [Schooling movements, living conditions and accessibility policies in university]. Revue des sciences de l'éducation, 17(3), 437-463.

Draelants, H. (2013). L'effet établissement sur la construction des aspirations d'études supérieures [The school effect on the construction of higher education aspirations]. L'orientation scolaire et professionnelle, 42(1), 3-32.

Dronkers, J., \& Avram, S. (2009). Choice and effectiveness of private and public schools in seven countries. A reanalysis of three PISA data sets. Zeitschrift für Pädagogik, 55(6), 895-909.

Dronkers, J., \& Robert, P. (2008). Differences in scholastic achievement of public, private governmentdependent, and private independent schools: A cross-national analysis. Educational Policy, 22(4), 541-577.

Dubet, F., Duru-Bellat, M., \& Vérétout, A. (2010). Les sociétés et leur école: Emprise du diplôme et cohésion sociale [Societies and their school: Credentialism of graduation and social cohesion]. Paris: Seuil.

Dupriez, V., \& Dumay, X. (2006). Inequalities in school systems: Effect of school structure or of structure of society? Comparative Education, 42(2), 243-260.

Falabella, A. (2014). The performing school: The effects of market \& accountability policies. Archives/ Archivos Analíticos de Políticas Educativas, 22, 1-26.

Felouzis, G. (2009). Systèmes éducatifs et inégalités scolaires: Une perspective internationale [Educational Systems and School Inequalities: An international perspective]. SociologieS. Advance online publication. Retrieved from sociologies.revues.org/2977

Felouzis, G., Maroy, C., \& van Zanten, A. (2013). Les marchés scolaires: Sociologie d'une politique publique d'éducation [School markets: Sociology of a public education policy]. Paris: Presses Universitaires de France.

Felouzis, G., \& Perroton, J. (2007). Les «marchés scolaires»: Une analyse en termes d'économie de la qualité ["School markets": An analysis in terms of quality economics]. Revue de sociologie, 48(4), 693-722.

Felouzis, G., \& Perroton, J. (2009). Grandir entre pairs à l'école. Ségrégation ethnique et reproduction sociale dans le système éducatif français [Growing up with peers at school. Ethnic segregation and social reproduction in the French education system]. Actes de la recherche en sciences sociales, 180(5), 92-100.

Jenkins, S. P., Micklewright, J., \& Schnepf, S. V. (2008). Social segregation in secondary schools: How does England compare with other countries? Oxford Review of Education, 34(1), 21-37.

Kamanzi, P. C., \& Maroy, C. (2017). La stratification des établissements secondaires au Québec: Quels effets sur les chances d'accès à l'enseignement universitaire? [Stratification of secondary schools in Quebec: What effects on the chances of access to university education?]. In P. C. Kamanzi, G. Goastellec, \& P. Picard (Eds.), L'envers du décor. Massification de l'enseignement supérieur et justice sociale (pp. 62-83). Québec: Presses de l'Université du Québec.

Karsenti, T., \& Collin, S. (2013). TIC et éducation: Avantages, défis et perspectives futures [ICTs and education: Benefits, challenges and future prospects]. Éducation et francophonie, 41(1), 1-6.

Lessard, C., \& Levasseur, L. (2007). L'école publique généraliste est-elle en train de voir sa vocation transformée? [Is the vocation of general public schooling being transformed?] McGill Journal of Education, 42(3), 337-353.

Lubienski, C., Gulosino, C., \& Weitzel, P. (2009). School choice and competitive incentives: Mapping the distribution of educational opportunities across local education markets. American Journal of Education, 115, 601-647.

Marcotte-Fournier, A. (2015). Ségrégation scolaire et différenciation curriculaire au Québec [School segregation and curriculum differentiation in Quebec]. Canadian Journal for New Scholars in Education/Revue 
canadienne des jeunes chercheures et chercheurs en éducation, 999(999), 1-9.

Marcotte-Fournier, A., Bourdon, S., Lessard, A., \& Dionne, P. (2016). Une analyse des effets de composition du groupe-classe au Québec: Influence de la ségrégation scolaire et des projets pédagogiques [An analysis of class composition effects in Quebec: Influence of school segregation and pedagogical projects]. Education et sociétés, 38(2), 139-155.

Marks, G. N. (2005). Cross-national differences and accounting for social class inequalities in education. International Sociology, 20(4), 483-505.

Maroy, C., \& Kamanzi, P. C. (2017). Marché scolaire, stratification des établissements et inégalités d'accès à l'enseignement universitaire au Québec [School market, stratification of institutions and unequal access to university education in Quebec]. Recherches sociographiques, LVIII(3), 579-600.

Ministère de l'Éducation, du Loisir et du Sport. (2014). Indicateurs de l'Éducation [Educational indicators]. Éditions 2013. Québec: Gouvernement du Québec.

Ministère de l'Éducation. (1999). Indicateurs de l'éducation [Educational indicators]. Éditions 1999. Québec: Gouvernement du Québec.

Ministère de l'Enseignement supérieur, de la Recherche et de la Science. (2015). Statistiques de l'enseignement supérieur [Statistics of higher education]. Éditions 2013. Québec: Gouvernement du Québec.

Motel-Klingebiel, A., Tesch-Roemer, C., \& Von Kondratowitz, H.-J. (2005). Welfare states do not crowd out the family: Evidence for mixed responsibility from comparative analyses. Ageing \& Society, 25, 863-882.

Paradis, P. E. (2015). Analyse de la contribution économique des établissements privés au Québec [Analysis of the economic contribution of private institutions in Quebec] (Rapport final). Québec: APPECO Analyse Stratégique \& FEEP. Retrieved from www.feep.qc.ca/wp-content/uploads/2018/02/App Eco_Analyse-contribution-economique_eco-priv-qc. pdf

Pechar, H., \& Andres, L. (2011). Higher education policies and welfare regimes: International comparative perspectives. Higher Education Policy, 24(1), 25-52.

Rompré, G. (2015). La mixité sociale à l'école [Social diversity in schools] (Rapport CSE-CNESCO: Conférence de comparaisons internationales). Québec et Paris: Conseil supérieur de l'Education et Conseil national de l'Évaluation du système scolaire de la France.

Savard, D., \& Bouthaïm, S. (2006). Les cégeps: De l'accès à la réussite [CEGEPs: From access to success]. In L. Héon, D. Savard, \& T. Hamel (Eds.), Les cégeps: Une grande aventure collective québécoise (pp. 91-139). Québec: Presses de l'Université Laval.

Sheldrake, R. (2016). Differential predictors of underconfidence and over-confidence for mathematics and science students in England. Learning and Individual Differences, 49, 305-313.

Sylvain, L., Laforce, L., \& Trottier, C. (1985). Les cheminements scolaires des francophones, des anglophones et des allophones du Québec au cours des années 70 [School pathways of Francophones, Anglophones and Allophones in Quebec in the 1970s]. Québec: Conseil de la langue française.

Teelken, C. (1999). Market mechanisms in education: School choice in the Netherlands, England and Scotland in a comparative perspective. Comparative Education, 35(3), 283-302.

Teese, R. (1998). Curriculum hierarchy, private schooling, and the segmentation of Australian secondary education, 1947-1985. British Journal of Education, 19(3), 401-417.

Van Zanten, A. (2006). Compétition et fonctionnement des établissements scolaires: Les enseignements d'une enquête européenne [Competition and the functioning of schools: Lessons from a European survey]. Revue française de pédagogie, 156, 9-17.

Van Zanten, A. (2009). Le choix des autres. Jugements, stratégies et ségrégations scolaires [The choices of others. Judgments, strategies and segregation]. Actes de la recherche en sciences sociales, 180(5), 24-34.

Whelan, C., Nolan, B., Esping-Andersen, G., Maitre, B., \& Sander, W. (2012). The role of social institutions in intergenerational mobility. In T. M. Smeeding, R. Erikson, \& J. Markus (Eds), Persistence, power and privilege: The comparative study of intergnerational mobility (pp. 331-367). New York, NY: Russell Sage Foundation.

Whitty, G. (1997). Creating quasi-markets in education: A review of recent research on parental choice and school autonomy in three countries. Review of Research in Education, 22(1), 3-47.

\section{About the Author}

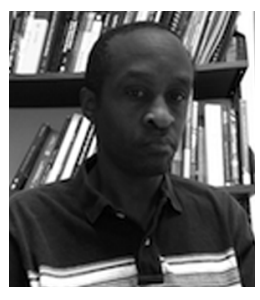

Pierre Canisius Kamanzi is Associate Professor at the University of Montreal (Province of Quebec, Canada), Faculty of Education. His research concerns economics and sociology of education. His main research topics are education policy analysis, educational trajectories and social inequalities. With Gaële Goastellec and France Picard, he recently published L'envers du Décor. Massification de L'enseignement Supérieur et Justice Sociale (2017). 